\title{
Performance and nutritional parameters of lactating cows on pasture receiving castor bean meal
}

\section{Desempenho e parâmetros nutricionais de vacas lactantes em pastejo recebendo farelo de mamona}

\author{
Dicastro Dias de Souza ${ }^{1 *}$; Fabiano Ferreira da Silva ${ }^{2}$; Robério Rodrigues Silva²; \\ Antonio Ferraz Porto Junior ${ }^{1}$; Leidiane Reis Pimentel ${ }^{1}$; Bismarck Moreira \\ Santiago $^{3}$; Andrêssa Pires dos Santos ${ }^{4}$; Thatiane Mota Vieira ${ }^{5}$; Wêndel Bispo \\ Santos e Santos ${ }^{5}$; Agnaldo Rios da Silva ${ }^{5}$
}

\begin{abstract}
This study aimed to evaluate the inclusion of castor bean meal in the diet for lactating cows on Bracharia brizhanta pasture and its implications for nutritional and productive parameters. Eight crossbred cows were distributed in two 4 x 4 Latin squares, with four $(0 \% ; 3.33 \%$; $6.66 \%$ and $10 \%)$ inclusion levels of castor bean meal in the total diet. The experiment consisted of four experimental periods of 21 days each. The digestibility and dry matter intake were estimated from fecal output, checked with the aid of external (chromium oxide) and internal (iNDF) indicators. Urine and milk were collected to determine the nitrogen balance and microbial protein production. The inclusion of different levels of castor bean meal in the diet for lactating cows did not affect the intake of dry matter and nutrients, and the same lack of effect was found for the digestibility of dry matter and total digestible nutrients, variation in body weight, milk production, chemical composition of milk, microbial production and nitrogen balance. The inclusion of up to $10 \%$ castor bean meal in the total diet did not influence productive parameters evaluated, and the use was conditioned to the price of castor bean meal.
\end{abstract}

Key words: Nitrogen balance. Consumption. Milk production. Microbial protein.

\section{Resumo}

Objetivou-se avaliar a inclusão de farelo de mamona na alimentação de vacas lactantes em pastejo de Bracharia brizhanta e suas implicações nos parâmetros nutricionais e produtivos. Foram utilizadas oito vacas mestiças distribuídas em dois quadrados latinos $4 \times 4$, com quatro níveis de inclusão de farelo de mamona na ração total; $0 \% ; 3,33 \% ; 6,66 \%$ e $10 \%$. O experimento foi constituído de quatro períodos experimentais, com duração de 21 dias cada. A digestibilidade e o consumo de matéria seca foram estimados a partir da produção fecal, verificada com o auxílio de indicadores externo (oxido de cromo) e interno (FDNi). Foi feita a coleta de urina e leite para determinação do balanço de nitrogênio

1 Discentes de Doutorado, Programa de Pós-Graduação em Zootecnia, Universidade Estadual do Sudoeste da Bahia, UESB, Itapetinga, BA, Brasil. E-mail: dicastrozootecnista@gmail.com; ferrazporto@hotmail.com; leidyrp@yahoo.com.br

2 Profs., Departamento de Tecnologia Rural e Animal, UESB, Itapetinga, BA, Brasil. E-mail: ffsilva@pq.cnpq.br; rrsilva.uesb@ hotmail.com

3 Discente de Mestrado, Programa de Pós-Graduação em Zootecnia, UESB, Itapetinga, BA, Brasil. E-mail: bismarck.santiago@ hotmail.com

4 Discentes de Graduação em Zootecnia, UESB, Itapetinga, BA, Brasil. E-mail: apzootecnia@outlook.com; thatiane.mvieira16@ live.com; wendelsantos@outlook.com; agnaldo.rios@outlook.com

* Author for correspondence 
e produção de proteína microbiana. $\mathrm{O}$ aumento dos níveis de farelo de mamona não influenciou o consumo de matéria seca e dos nutrientes. Para o coeficiente de digestibilidade da matéria seca e dos nutrientes digestíveis totais não foi observado diferença estatísticas. Para a variação do peso corporal, produção de leite, composição química do leite não houve diferença entre os diferentes níveis de farelo de mamona, assim também aconteceu com a produção microbiana e balanço de nitrogênio. A inclusão de até $10 \%$ de farelo de mamona na dieta total não influenciou os parâmetros produtivos avaliados, ficando condicionado o uso, ao preço do farelo de mamona.

Palavras-chave: Balanço de nitrogênio. Consumo. Produção de leite. Proteína microbiana.

\section{Introduction}

Castor bean (Ricinus comunis L.) is an oilseed native to Ethiopia belonging to the family Euphorbaceae, used for oil extraction and biodiesel production, but it has a low yield per area in relation to its potential (RIBEIRO, et al., 2009). Among the agroindustrial co-products, castor bean meal may become a source of protein in the lactating cows diet, as well as an alternative source to products commonly used to feed animals such as soybean, sunflower and cotton, which have higher prices than castor bean meal (ABDALLA et al., 2008).

Despite the potential of castor bean meal in dairy cattle nutrition, which can add value to this product, it is still little used due to the presence of 3 compounds toxic to animals: ricin, ricinin and allergenic complexes (ALEXANDER et al., 2008). According to the aforementioned authors, the main compound is ricin, which is a toxic protein present in seeds and is part of a broad family of enzymes known as Ribosomal Inhibitory Proteins (RIP) that are able to inactivate ribosomes, breaking the bond between adenine and ribose, thereby making protein synthesis impossible, leading to cell death and as a consequence the death of the animal.

Protein, followed by energy, is the nutrient most required by ruminants, and among dietary components, protein is the most expensive ingredient and the cost of using these foods is highly dependent on the efficiency of their use. Due to this, there was considerable interest in maximizing the point of use of nitrogen compounds in the diet, aiming at reducing production costs and minimizing the losses of these compounds in urine and feces (VALADARES et al., 1999), as well as reducing environmental pollution.

In addition, one way to attenuate the limitation of essential amino acids for milk production is to create means to potentiate the production of microbial protein, since it is of high biological value and compared with other sources of protein commonly used in dairy cattle feeding, it is the most balanced in amino acids. According to AndradeMontemayor et al. (2009), quantifying the synthesis of microbial protein is one of the most interesting aspects in studies with protein feed for ruminants, because it is a protein of high biological value.

In this way, the goal of the present study was to evaluate the inclusion of four levels of castor bean meal in the diets for dairy cows on pasture, by means of performance, intake and digestibility of nutrients, nitrogen balance, microbial protein synthesis and microbial protein synthesis efficiency.

\section{Material and Methods}

The experiment was conducted at the Valeu Boi Farm, in the municipality of Encruzilhada, state of Bahia, and at the Forage Laboratory, State University of Southwestern Bahia - UESB. Eight Holstein $\mathrm{x}$ Zebu crossbred cows with a breed composition varying from $1 / 2$ to $3 / 4 \mathrm{H} \mathrm{x} \mathrm{Z}$ blood, from third to fifth lactation, with average milk production adjusted for 300 days in the previous lactation, between 5,000 and $6,000 \mathrm{~kg}$ and average body weight of $509.47 \pm 61.90 \mathrm{~kg}$ were selected 
considering lactation days, between $100.33 \pm 13.33$ days at the beginning of the experimental period, which was on February $11^{\text {st }}, 2014$ and ended on March $5^{\text {th }}, 2014$, with a duration of 21 days each. The first 15 days were used for adaptation and the other six days for data collection. The cows were distributed in two $4 \times 4$ Latin Squares, with four inclusion levels of castor bean meal in the total diet (Table 1). Feed was composed of concentrate and the forage was Brachiaria brizantha pasture in an intermittent grazing system with a duration of one day in each paddock with a stocking rate of $1.0 \mathrm{AU}$ ha $^{-1}$.

The composition of the concentrate (Table 1) was defined by the balance of the feed, in order to contain enough nutrients for maintenance, gain of body weight of $0.15 \mathrm{~kg} \mathrm{day}^{-1}$ and milk production of $25 \mathrm{~kg} \mathrm{day}^{-1}$, according to NRC (2001), based on data of chemical composition of Brachiaria brizanta grass, corn, soybean meal, cottonseed and castor bean meal, performed one week before the experimental period.

Table 1. Proportions of concentrate ingredients on a dry matter basis and forage: concentrate ratio for lactating cows fed different levels of castor bean meal.

\begin{tabular}{lcccc}
\hline Ingredient \% & \multicolumn{3}{c}{ Treatment } \\
\cline { 2 - 5 } & $0.00 \%$ & $3.33 \%$ & $6.66 \%$ & $10.00 \%$ \\
\hline Ground corn & 55.52 & 53.80 & 52.11 & 50.46 \\
Cottonseed & 23.68 & 23.37 & 23.10 & 22.81 \\
Soybean meal & 16.34 & 10.92 & 5.62 & 0.44 \\
Castor bean meal & 0.00 & 7.60 & 15.01 & 22.27 \\
Urea & 1.34 & 1.32 & 1.31 & 1.29 \\
Limestone & 1.25 & 1.15 & 1.03 & 0.93 \\
Mineral salt & 1.87 & 1.85 & 1.82 & 1.80 \\
\hline & \multicolumn{4}{c}{43.59} \\
\hline Forage & Ratio \% & 44.70 & 44.52 \\
Concentrate & 43.26 & 55.30 & 55.48 & 56.41 \\
\hline
\end{tabular}

${ }^{1}$ Composition: Calcium $200 \mathrm{~g}$; Cobalt $200 \mathrm{mg}$; Copper $1.650 \mathrm{mg}$; Sulfur $12 \mathrm{~g}$; Iron $560 \mathrm{mg}$; Fluorine (max) $1000 \mathrm{~g}$; Phosphorus 100 g; Iodine 195 mg; Magnesium 15 g; Mangaese 1960 mg; Nickel 40 mg; Selenium 32 mg; Sodium 68 $\mathrm{g}$; Zinc $6285 \mathrm{mg}$.

The castor bean meal was purchased from a biodiesel company located in the metropolitan region of Salvador, treated before the onset of the experiment with calcium oxide following the methodology of Oliveira (2008), which consists of the treatment of $1000 \mathrm{~g}$ meal with $60 \mathrm{~g}$ calcium hydroxide $\left(\mathrm{Ca}(\mathrm{OH})_{2}\right)$ at $60^{\circ} \mathrm{C}$ for 8 hours, for detoxification.
For concentrate consumption, the animals were housed in individual, $16 \mathrm{~m}^{2}$ covered stalls, provided with individual plastic troughs. The concentrate was offered twice a day, at 8:00 AM after milking and 4:00 PM before milking. In each experimental period, the forage and supplements were collected to evaluate the chemical composition (Table 2). 
Table 2. Chemical composition of Brachiaria brizanta, castor bean meal and concentrate.

\begin{tabular}{lcccccc}
\hline \multicolumn{1}{c}{ Nutrients } & Castor bean meal & ${\text { Brachiaria } \text { brizanta }^{1}}^{1}$ & \multicolumn{4}{c}{ Treatment } \\
\cline { 4 - 6 } & & & $0.00 \%$ & $3.33 \%$ & $6.66 \%$ & $10.00 \%$ \\
\hline $\mathrm{DM}^{2}$ & 88.98 & 25.68 & 88.09 & 87.97 & 87.56 & 88.02 \\
$\mathrm{OM}^{3}$ & 70.90 & 92.89 & 92.01 & 91.35 & 90.68 & 90.01 \\
$\mathrm{CP}^{4}$ & 32.39 & 8.23 & 20.68 & 20.81 & 21.15 & 19.98 \\
$\mathrm{EE}^{5}$ & 3.30 & 5.65 & 7.50 & 7.09 & 7.62 & 7.74 \\
$\mathrm{NFC}^{6}$ & 4.73 & 11.18 & 46.51 & 48.83 & 44.98 & 39.58 \\
$\mathrm{NDFcp}^{7}$ & 30.48 & 67.82 & 17.32 & 14.61 & 16.92 & 22.81 \\
$\mathrm{ADF}^{8}$ & 43.81 & 54.99 & 16.05 & 16.49 & 17.64 & 15.33 \\
$\mathrm{MM}^{9}$ & 29.10 & 7.11 & 7.98 & 8.65 & 9.33 & 9.91 \\
\hline
\end{tabular}

${ }^{1}$ Simulated Grazing; ${ }^{2} \mathrm{DM}$ - Dry Matter; ${ }^{3} \mathrm{OM}$ - Organic Matter; ${ }^{4} \mathrm{CP}$ - Crude Protein; ${ }^{5} \mathrm{EE}$ - Ether Extract; ${ }^{6} \mathrm{NFC}$ Non-Fiber Carbohydrate; ${ }^{7} \mathrm{NDF} p \mathrm{-}$ - Neutral Detergent Fiber corrected for ash and protein, ${ }^{8} \mathrm{ADF}-$ Acid Detergent Fiber ${ }^{9} \mathrm{MM}-$ Mineral Matter.

Pastures were evaluated at the beginning of each experimental period, by cutting 12 samples, which were weighed on a digital scale accurate to 5 grams. After homogenizing the forage collected, a composite sample was formed for separation into leaf blade, stem and dead material. With the values of the cut and visually estimated samples, it was possible to calculate the amount of forage biomass available per paddock, expressed in kg DM.ha-1. Availability and allowance of forage during the experiment are listed in Table 3. During the experimental period, the environmental temperature (Table 4) was recorded on the farm, using a digital thermometer.

Table 3. Availability and allowance of forage for the experimental periods.

\begin{tabular}{lccccc}
\hline & \multicolumn{5}{c}{ Experimental period } \\
\cline { 2 - 5 } & 1 & 2 & 3 & 4 & Mean \\
\hline Forage mass kg ha $^{-1}$ & 2421.23 & 3419.50 & 1182.32 & 1226.94 & 2062.50 \\
FA $^{1} \mathrm{~kg} \mathrm{MS} \mathrm{100} \mathrm{kg} \mathrm{PV}^{-1}$ & 7.68 & 10.81 & 3.74 & 3.88 & 6.53 \\
Leaf\% & 35.60 & 19.43 & 30.35 & 25.33 & 27.67 \\
Stem\% & 42.41 & 65.40 & 44.64 & 44.80 & 49.31 \\
Dead material\% & 22.59 & 15.16 & 25 & 29.87 & 23.15 \\
Leaf: stem & 0.84 & 0.29 & 0.68 & 0.56 & 0.59 \\
\hline
\end{tabular}

${ }^{2}$ Forage allowance.

Table 4. Mean, maximum and minimum temperature per month, during the experimental period.

\begin{tabular}{lcccc}
\hline Variables & \multicolumn{4}{c}{ Month } \\
\cline { 2 - 5 } & February & March & April & May \\
\hline Maximum temperature $\left({ }^{\circ} \mathrm{C}\right)$ & 30.24 & 30.10 & 27.87 & 21.9 \\
Minimum temperature $\left({ }^{\circ} \mathrm{C}\right)$ & 23.72 & 23.44 & 22.12 & 19.93 \\
Mean temperature $\left({ }^{\circ} \mathrm{C}\right)$ & 26.97 & 26.78 & 24.95 & 20.92 \\
\hline
\end{tabular}


Milk production was evaluated from the $16^{\text {th }}$ to the $21^{\text {st }}$ day of each experimental period, and two milkings per day were performed at 5:00 a.m. and 5:00 p.m., when immediately after milking the milk was weighed on a digital scale with capacity of 30 $\mathrm{kg}$. Milk samples from the milkings performed on the $12^{\text {nd }}$ day were collected from each animal to determine protein, fat, lactose and total solids using the Lactoscan ${ }^{\circledR}$ digital apparatus. The production of milk corrected (PMC) to 3.5\% fat was estimated according to the model proposed by Sklan et al. (1992), by the following equation:

$$
\mathrm{PMC}=((0.432+0.1625 \times \mathrm{EEM}) \times \mathrm{MP})
$$

Where, $\mathrm{PMC}=$ production of milk corrected to $3.5 \%$ fat, $\% \mathrm{EEM}=$ ether extract content of the milk and $\mathrm{MP}=$ Milk production in kg.day ${ }^{-1}$.

At the end of each experimental period, the concentrate, forage, and feces were collected and packed in plastic bags and then stored in a freezer for chemical analysis. After the completion of the experimental period, the samples were pre-dried and ground in a mill with $1 \mathrm{~mm}$ sieve; and then stored in a glass with a lid, previously identified, and stored for further analysis.

The analyses of dry matter (DM), crude protein (CP), ether extract (EE), acid detergent fiber (ADF) and mineral matter (MM) of the diets were performed according to Detmann et al. (2012). The neutral detergent fiber, free of ash and protein (NDFcp), was calculated according to Mertens (1997). The non-fiber carbohydrates (NFC) of the samples that did not contain urea were calculated by the equation proposed by Hall (2000):

$$
\mathrm{NFC}=100-(\% \mathrm{CP}+\% \mathrm{EE}+\% \mathrm{Ash}+\% \mathrm{NDFcp})
$$

Where $\% \mathrm{CP}=$ crude protein content, $\% \mathrm{EE}=$ ether extract content, \%Ash $=$ ash content and $\% \mathrm{NDF} c \mathrm{p}=$ neutral detergent fiber corrected for ash and protein.

The NFC of the samples containing urea was calculated with the equation proposed by Hall (2000), using the formula:
$\mathrm{NFC}=100-((\% \mathrm{CP}-\% \mathrm{CPU}+\% \mathrm{U})+\% \mathrm{MM}+$ $\% \mathrm{EE}+\% \mathrm{NDFcp})$

Where, $\% \mathrm{CPU}=$ crude protein content from urea and $\% \mathrm{U}=$ urea content.

The content of total digestible nutrients (TDN) was calculated according to NRC (2001):

$\mathrm{TDN}=\mathrm{DCP}+\mathrm{DEE} \times 2.25+\mathrm{DNDF}+\mathrm{DNFC}$

Where: $\mathrm{DCP}=$ digestible crude protein; $\mathrm{DEE}=$ digestible ether extract; DNDF = digestible neutral detergent fiber; DNFC = digestible non-fiber carbohydrates.

In all the days of the experimental period, the pasture was collected by simulated grazing, observing the grazing of the animals, identifying the type of material consumed, simulating the material ingested by the animal, according to the methodology of Johnson (1978).

The apparent digestibility and the dry matter intake (DMI) were estimated from fecal output, using all cows. Chromium oxide was used as an external indicator to estimate the fecal output of the animals and the indigestible neutral detergent fiber (iNDF) as internal indicator to estimate the forage intake.

Blood samples were collected on the last day of each period, obtaining $10 \mathrm{~mL}$, through the mammary vein, with vacutainer tubes containing sodium heparin and anticoagulant. They were then centrifuged (1500 ppm for 15 minutes) to separate the plasma. After centrifugation, the plasma was kept in Eppendorf tubes under refrigeration (icebox) for transportation to the laboratory, where they were stored at $-20{ }^{\circ} \mathrm{C}$ for further analysis of urea concentrations.

During the collection period, spot urine samples were taken on the $18^{\text {th }}$ day of each experimental period, approximately 4 hours after feeding, during spontaneous urination, as described by Valadares et al. (1999). A $10 \mathrm{~mL}$ aliquot was diluted in $40 \mathrm{~mL}$ $0.036 \mathrm{~N}$ sulfuric acid. The $\mathrm{pH}$ was measured and, 
whenever necessary, adjusted to values below 3 by adding concentrated sulfuric acid to the desired $\mathrm{pH}$ in order to prevent bacterial destruction of purine derivatives and precipitation of uric acid. Urine samples were stored at $-20^{\circ} \mathrm{C}$ and then analyzed for creatinine, urea, uric acid and allantoin concentrations.

Concentration of urea in plasma, in urine, and in deproteinized milk and concentrations of creatinine and uric acid in urine were determined using commercial kits $\left(\right.$ Bioclin $\left.^{\circledR}\right)$ according to the manufacturer's instructions.

Data, with the exception of economic viability, were evaluated through analysis of variance and regression analysis. The statistical models were selected according to the significance of the regression coefficients using the F-test at 5\% probability level and the coefficient of determination $\left(\mathrm{R}^{2}\right)$.

\section{Results and Discussion}

There was no effect of castor bean meal on dry matter intake in $\mathrm{Kg}$.day ${ }^{-1}$ and in $\% \mathrm{BW}$, and the intake of crude protein and total digestible nutrients were also not affected (Table 5). Cobianchi et al. (2012), who worked with different levels of inclusion of castor bean meal in lactating cows feed, obtained maximum dry matter intake with the inclusion of $5 \%$ in the total diet, different from that found in the present study. This difference may be due to the heterogeneity of castor bean byproducts.

Table 5. Intake of dry matter and nutrients of lactating cows receiving different levels of castor bean meal in the diet.

\begin{tabular}{lccccccc}
\hline Intake $\left(\mathrm{kg} \mathrm{day}^{-1}\right)$ & \multicolumn{9}{c}{ Treatment } & $\hat{\mathrm{Y}}^{1}$ & $\mathrm{CV}^{2}$ & $\mathrm{P}^{3}$ \\
\hline Dry matter $\left(\mathrm{kg} \mathrm{day}^{-1}\right)$ & $0.00 \%$ & $3.33 \%$ & $6.66 \%$ & $10.00 \%$ & & & \\
Crude protein $\left(\mathrm{kg} \mathrm{day}^{-1}\right)$ & 12.98 & 13.44 & 13.69 & 13.48 & 13.40 & 7.45 & 0.547 \\
NDFcp $^{4}\left(\mathrm{~kg} \mathrm{day}^{-1}\right)$ & 1.93 & 2.00 & 2.04 & 1.95 & 1.98 & 3.76 & 0.051 \\
${\text { Ether extract }\left(\mathrm{kg} \mathrm{day}^{-1}\right)}^{5.10}$ & 5.24 & 5.50 & 5.51 & 5.34 & 12.82 & 0.563 \\
TDN $^{5}\left(\mathrm{~kg} \mathrm{day}^{-1}\right)$ & 0.88 & 0.89 & 0.95 & 0.93 & 0.91 & 6.61 & 0.113 \\
Dry matter $(\% \mathrm{BW})$ & 8.63 & 8.94 & 9.04 & 8.79 & 8.85 & 8.89 & 0.743 \\
NDFcp $^{4}(\% \mathrm{BW})$ & 2.51 & 2.59 & 2.64 & 2.61 & 2.59 & 11.50 & 0.821 \\
\hline
\end{tabular}

${ }^{1}$ Regression equations; ${ }^{2}$ Coefficient of variation in percentage; ${ }^{3}$ Probability of error; ${ }^{4}$ Neutral detergent fiber corrected for ash and crude protein; ${ }^{5}$ Total digestible nutrients.

The low DMI in relation to the other studies with pastured dairy cattle (PIMENTEL et al., 2011) is related to the low availability and allowance of forage (Table 3), due to the climatic conditions, mainly the lack of rainfall, which was expected during the course of the experiment. According to Silva et al. (2009), the availability of forage is directly related to the total DMI, so when the animal is subjected to forage shortage, it results in a reduction in DMI, and the animal needs to increase the grazing time. Thus, if minimum forage allowance is guaranteed, according to Schio et al. (2011), there may be a positive effect on DMI and production.

The inclusion of castor bean meal in the feed for dairy cows did not influence the intake of neutral detergent fiber corrected for ash and protein (NDFcp), expressed in $\mathrm{kg}$ day $^{-1}$ and\%BW. This lack of difference is due to the balance of the diet, 
since there were different proportions of forage and concentrate to balance the energy, as can be observed with the NDFcp contents of the diets in Table 2. The values found for CNDFep in $\% \mathrm{BW}$ of $1.09 \% \mathrm{BW}$ are below values found in the literature, in which, Oliveira et al. (2012) reported in a literature review the overall average for the intake of $1.6 \%$ NDF in relation to the body weight.

The intake of EE $(6.79 \%$ DMI) was not influenced by levels of castor bean cake in the diet, and EE intake is above that recommended by Mir et al. (2001), which is $6 \%$ on a dry matter basis, which can lead to reduced intake, due to the reduced fiber digestibility (AFERRI et al., 2005; JORDAN et al., 2006).

There was no effect of castor bean meal on the coefficient of digestibility of dry matter and crude protein (Table 6), which is explained by the homogeneity of the diets.

Table 6. Coefficient of digestibility of dry matter and nutrients in lactating cows fed different levels of castor bean meal in the diet.

\begin{tabular}{lccccccc}
\hline Digestibility (\%) & \multicolumn{9}{c}{ Treatment } & $\hat{\mathrm{Y}}^{1}$ & $\mathrm{CV}^{2}$ & $\mathrm{P}^{3}$ \\
\cline { 2 - 5 } & $0.00 \%$ & $3.33 \%$ & $6.66 \%$ & $10.00 \%$ & & & \\
\hline Dry matter & 56.43 & 58.86 & 58.38 & 57.61 & 57.82 & 5.33 & 0.441 \\
Crude protein & 68.87 & 70.23 & 71.47 & 70.77 & 70.33 & 5.42 & 0.581 \\
NDFcp $^{4}$ & 39.51 & 39.26 & 40.36 & 41.05 & 40.05 & 16.33 & 0.943 \\
Total digestible nutrients & 66.53 & 66.45 & 66.08 & 65.18 & 66.06 & 4.71 & 0.814 \\
\hline
\end{tabular}

${ }^{1}$ Regression equations; ${ }^{2}$ Coefficient of variation in percentage; ${ }^{3}$ Probability of error; ${ }^{4}$ Neutral detergent fiber corrected for ash and crude protein.

For the digestibility of NDFcp (Table 6), there was no effect of castor bean meal inclusion; however, there was a lower digestibility than that found in the literature (PIMENTEL et al., 2011; SILVA et al. 2009), which is due to the amount of EE consumed. The excess of this nutrient, according to Jenkins and Mcguire (2006), has a toxic effect on the microorganism, inhibiting the cellular growth, mainly the cellulolytic bacteria that acts mainly in the digestion of the cellular wall, and also the excess of fat can generate a fiber encapsulation, making it difficult the microbial adhesion to the cell wall.

There was no difference in milk production, corrected to $3.5 \%$ fat, feed efficiency and body weight variation with the inclusion of castor bean meal in the diet (Table 7). This effect can be explained by the lack of difference in the intake of dry matter and other nutrients and also in the digestibility of the same. 
Table 7. Performance of lactating cows fed different levels of castor bean in the diet.

\begin{tabular}{lccccccc}
\hline Performance & \multicolumn{9}{c}{ Treatment } & $\hat{\mathrm{Y}}^{1}$ & $\mathrm{CV} \%^{2}$ & $\mathrm{P}^{3}$ \\
\cline { 2 - 5 } & $0.00 \%$ & $3.33 \%$ & $6.66 \%$ & $10.00 \%$ & & & \\
\hline Milk production $\left(\mathrm{kg} \mathrm{day}^{-1}\right)$ & 15.27 & 16.84 & 16.20 & 15.45 & 15.94 & 4.98 & 0.301 \\
Milk production $\mathrm{G}^{4}\left(\mathrm{~kg} \mathrm{day}^{-1}\right)$ & 19.04 & 20.56 & 19.81 & 19.58 & 19.75 & 7.59 & 0.269 \\
$\mathrm{FE}^{5}\left(\mathrm{~kg} \mathrm{milk} \mathrm{IDM}^{-1}\right)$ & 1.18 & 1.26 & 1.18 & 1.15 & 1.19 & 8.20 & 0.219 \\
$\mathrm{BWV}^{6}\left(\mathrm{~kg} \mathrm{period}^{-1}\right)$ & 7.12 & 5.00 & 8.65 & 4.41 & 6.30 & 130.19 & 0.716 \\
\hline
\end{tabular}

${ }^{1}$ Regression equations; ${ }^{2}$ Coefficient of variation in percentage; ${ }^{3}$ Probability of error; ${ }^{4}$ Milk production corrected to $3.5 \%$ fat; ${ }^{5}$ Feed efficiency; ${ }^{6}$ Body weight variation.

Corrected milk production had an average of $19.75 \mathrm{~kg}$, below the expected production, which was $25 \mathrm{~kg}$ according to the Tables of NRC requirements (2001). This difference may be because NRC (2001) is not adequate for the tropical conditions or due to the limited genetic potential of the animals, since instead of producing the estimated amount of milk, they increased body weight.

Although the body weight variation was not different, it can be observed an increase in the weight gain of the animals in all the treatments, although this parameter was not evaluated in the study, this condition can increase the reproductive efficiency of the herd.

There was no effect on milk composition (Table 8) when the levels of castor bean in the diet were increased, and this is a consequence of the degree of similarity of the experimental diets, since the use of concentrate increases production, but has little influence on milk composition (TEIXEIRA et al., 2006).

Table 8. Milk composition of lactating cows fed different levels of castor bean in the diet.

\begin{tabular}{lccccccc}
\hline Composition & \multicolumn{9}{c}{ Treatment } & $\hat{\mathrm{Y}}^{1}$ & $\mathrm{CV}^{2}$ & $\mathrm{P}^{3}$ \\
\cline { 2 - 5 } & $0.00 \%$ & $3.33 \%$ & $6.66 \%$ & $10.00 \%$ & & & \\
\hline Protein & 3.95 & 3.94 & 3.96 & 3.93 & 3.95 & 1.29 & 0.681 \\
Fat & 5.03 & 4.83 & 4.85 & 5.15 & 4.97 & 7.99 & 0.343 \\
Lactose & 5.13 & 5.18 & 4.82 & 4.97 & 5.03 & 8.88 & 0.390 \\
Defatted solids & 9.48 & 9.19 & 9.18 & 9.71 & 9.39 & 4.74 & 0.082 \\
Total solids & 13.20 & 13.22 & 13.19 & 13.29 & 13.23 & 1.77 & 0.825 \\
\hline
\end{tabular}

${ }^{1}$ Regression equations; ${ }^{2}$ Coefficient of variation in percentage; ${ }^{3}$ Probability of error.

Nevertheless, the fat content of milk was higher than that found for supplemented cattle on pasture (SILVA et al., 2009), possibly due to the high level of zebu blood of some animals used in this work.

Further, for the variables analyzed in the balance of nitrogen compounds (Table 9), no difference was detected with the increase of inclusion of castor bean meal in the diet. This may be because that there is no alteration in the dry matter intake between the diets, since they were formulated to be isoproteic. 
Table 9. Balance of nitrogen compounds in lactating cows fed diets containing different levels of castor bean meal.

\begin{tabular}{|c|c|c|c|c|c|c|c|}
\hline \multirow[t]{2}{*}{ Balance of nitrogen compounds } & \multicolumn{4}{|c|}{ Treatment } & \multirow[t]{2}{*}{$\hat{\mathrm{Y}}^{1}$} & \multirow[t]{2}{*}{$\mathrm{CV} \%{ }^{2}$} & \multirow[t]{2}{*}{$\mathrm{P}^{3}$} \\
\hline & $0.00 \%$ & $3.33 \%$ & $6.66 \%$ & $10.00 \%$ & & & \\
\hline $\mathrm{N}$ ingested $\left(\mathrm{g} \mathrm{day}^{-1}\right)$ & 317.24 & 324.93 & 333.72 & 319.20 & 323.77 & 4.00 & 0.084 \\
\hline $\mathrm{N}$ in feces $\left(\mathrm{g} \mathrm{day}^{-1}\right)$ & 92.29 & 92.87 & 101.36 & 91.11 & 94.41 & 15.15 & 0.479 \\
\hline $\mathrm{N}$ in mik $\left(\mathrm{g} \mathrm{day}^{-1}\right)$ & 84.07 & 98.24 & 90.38 & 84.00 & 89.17 & 12.58 & 0.064 \\
\hline $\mathrm{N}$ in urine $\left(\mathrm{g} \mathrm{day}^{-1}\right)$ & 15.91 & 16.98 & 15.29 & 15.84 & 16.01 & 33.98 & 0.938 \\
\hline $\mathrm{N}$ retained $\left(\mathrm{g} \mathrm{day}^{-1}\right)$ & 124.97 & 116.84 & 126.68 & 128.25 & 124.18 & 16.68 & 0.700 \\
\hline $\mathrm{N}$ retained (\% $\mathrm{N}$ ing.) & 39.27 & 35.97 & 37.83 & 40.25 & 38.33 & 15.73 & 0.528 \\
\hline
\end{tabular}

${ }^{1}$ Regression equations; ${ }^{2}$ Coefficient of variation in percentage; ${ }^{3}$ Probability of error.

There was no effect of the treatments on nitrogen excretion in milk ( $\mathrm{N}$ milk), consistent with the lack of responses observed for milk production and protein content. The higher the milk yield, the greater the excretion of $\mathrm{N}$ in milk.

According to Azevedo et al. (2010), the surplus of $\mathrm{N}$ in the rumen is absorbed by the ruminal epithelium, falls into the bloodstream, in which one part is excreted via feces, urine and milk and the other is recycled by saliva. Alves et al. (2010) stated that several factors that affect the efficiency of nitrogen utilization include the animals' breed composition, the order and stage of lactation, the concentration of milk protein, the carbohydrate source and the amount and quality of dietary protein.
Thus, when the nitrogen balance is positive, it is suggested that there was a retention of protein by the animal, without loss of muscle tissue, which probably means that the protein requirements were met (VASCONCELOS et al., 2010).

Microbial nitrogen, microbial crude protein and efficiency of microbial protein synthesis per kilogram of urinary volume TDN (Table 10) was not affected by the inclusion of castor bean meal in the diet, possibly because the experimental diets were isoproteic. The mean value of microbial $\mathrm{N}$ (Table 10) was close to that reported by Sousa et al. (2009), who worked with cows with production between 18 and $22 \mathrm{~kg}$. day ${ }^{-1}$.

Table 10. Microbial nitrogen, microbial protein synthesis and microbial efficiency of lactating cows receiving different levels of castor bean meal in the diet.

\begin{tabular}{|c|c|c|c|c|c|c|c|}
\hline \multirow[t]{2}{*}{ Item } & \multicolumn{4}{|c|}{ Treatment } & \multirow[t]{2}{*}{$\hat{\mathrm{Y}}^{1}$} & \multirow[t]{2}{*}{$\mathrm{CV} \%{ }^{2}$} & \multirow[t]{2}{*}{$\mathrm{P}^{3}$} \\
\hline & $0 \%$ & $3.33 \%$ & $6.66 \%$ & $10 \%$ & & & \\
\hline \multicolumn{8}{|c|}{ Microbial synthesis of N and CP (g/day) } \\
\hline Microbial N & 278.44 & 223.25 & 198.77 & 185.76 & 221.56 & 46.89 & 0.322 \\
\hline Microbial CP & 1383.41 & 1289.29 & 1158.41 & 1073.02 & 1226.03 & 52.15 & 0.775 \\
\hline \multicolumn{8}{|c|}{ Microbial efficiency } \\
\hline $\mathrm{g} \mathrm{CP} \mathrm{kg} \mathrm{TDN}^{-1}$ & 174.39 & 152.67 & 146.34 & 129.85 & 150.81 & 51.08 & 0.715 \\
\hline
\end{tabular}

${ }^{1}$ Regression equations; ${ }^{2}$ Coefficient of variation in percentage; ${ }^{3}$ Probability of error. 
The efficiency of microbial protein synthesis per kilogram TDN was not affected by the inclusion of castor bean meal in the diet (Table 10). The mean value found was $150.81 \mathrm{~g}$ of CPmic $\mathrm{kg} \mathrm{TDN}^{-1}$ consumed, higher than the value suggested by the NRC (2001), of $130 \mathrm{~g}$ of CPmic kg TDN ${ }^{-1}$. Pina et al. (2006) compiled several studies using animals for the production of meat and milk subjected to different feeding management, and recommended microbial efficiency of $120 \mathrm{~g} \mathrm{CPmic} \mathrm{kg} \mathrm{TDN}^{-1}$ as reference for tropical conditions. Results close to that found by Cobianchi et al. (2012), which found mean values for microbial efficiency at $126.4 \mathrm{~g}$ CPmic kg TDN ${ }^{-1}$, working with different levels of castor bean in the diet for lactating cows.

For Chizzotti et al. (2007), the production of microbial $\mathrm{N}$ and the synthesis of microbial $\mathrm{CP}$ is directly related to animals with different production and attributed this difference to the higher intake by the most productive animals, a fact not observed in the present study. Potentiating the microbial protein synthesis is important because it is the best source of available amino acids for synthesis and production of milk, since it has a good amino acid profile.

\section{Conclusion}

The inclusion of up to $10 \%$ castor bean meal in the total diet did not influence the productive performance; its use is conditioned to the price of castor bean meal.

\section{References}

ABDALlA, A. L.; SILVA FILHO, J. C.; GODOI, A. R.; CARMO, C. A.; EDUARDO, J. L. P. Utilização de subprodutos da indústria de biodiesel na alimentação de ruminantes. Revista Brasileira de Zootecnia, Viçosa, v. 37, p. 260-268, 2008. Suplemento Especial.

AFERRI, G.; LEME, P. R.; SILVA, S. L.; PUTRINO, S. M.; PEREIRA, A. S. C. Desempenho e características de carcaça de novilhos alimentados com dietas contendo diferentes fontes de lipídios. Revista Brasileira de Zootecnia, Viçosa, v. 34, n. 5, p. 1651-1658, 2005.
ALEXANDER, J.; ANDERSSON, H. C.; BERNHOFT, A.; BRIMER, L.; COTTRILL, B.; FINK-GREMMELS, J.; JAROSZEWSKI, J.; SOERENSEN, H. Ricin (from Ricinus communis) as undesirable substances in animal feed: scientific opinion of the panel on contaminants in the food chain. European Food Safety Authority (EFSA) Journal, Parma, v. 726, p. 1-38, 2008.

ALVES, A. F.; ZERVOUDAKIS, J. T.; ZERVOUDAKIS, L. K. H.; CABRAL, L. S.; LEONEL, F. P.; PAULA, N. F. Substituição do farelo de soja por farelo de algodão de alta energia em dietas para vacas leiteiras em produção: consumo, digestibilidade dos nutrientes, balanço de nitrogênio e produção leiteira. Revista Brasileira de Zootecnia, Viçosa v. 39, n. 3, p. 532-540, 2010.

ANDRADE-MONTEMAYOR, H.; GASCA, T. G.; KAWAS, J. Ruminal fermentation modification of protein and carbohydrate by means of roasted and estimation of microbial protein synthesis. Revista Brasileira de Zootecnia, Viçosa, v. 38, p. 277-291, 2009. Suplemento Especial.

AZEVEDO, E. B.; PATIÑO, H. O.; SILVEIRA, A. L. F. da; LÓPEZ, J.; NÖRNBERG, J. L.; BRÜNING, G. Suplementação nitrogenada com ureia comum ou encapsulada sobre parâmetros ruminais de novilhos alimentados com feno de baixa qualidade. Ciência Rural, Santa Maria v. 40, n. 3, p. 622-627, 2010.

CHIZZOTTI, M. L.; VALADARES FILHO, S. C.; VALADARES, R. F. D.; CHIZZOTTI, F. H. M.; MARCONDES, M. I.; FONSECA, M. A. Consumo, digestibilidade e excreção de uréia e derivados de purinas em vacas de diferentes níveis de produção de leite. Revista Brasileira de Zootecnia, Viçosa, v. 36, n. 1, p. 138-146, 2007.

COBIANCHI, J. V.; OLIVEIRA, A. S.; CAMPOS, J. M. S.; GUIMARÃES, A. V.; VALADARES FILHO, S. C.; COBIANCHI, F. P.; AND OLIVEIRA, T. E. S. Productive performance and efficiency of utilization of the diet components in dairy cows fed castor meal treated with calcium oxide. Revista Brasileira de Zootecnia, Viçosa, v 41, n. 10, p. 2238-2248, 2012.

DETMANN, E.; SOUZA, M. A.; VALADARES FILHO, S. C.; QUEIROZ, A. C.; BERCHIELLI, T. T.; SALIBA, E. O. S.; CABRAL, L. S.; PINA, D. S.; LADEIRA, M. M.; AZEVEDO, J. A. G. Métodos para análise de alimentos - INCT - Ciência Animal. Visconde do Rio Branco: Suprema, 2012. 214 p.

HALL, M. B. Neutral detergent-soluble carbohydrates: nutritional relevance and analysis, a laboratory manual. Gainesville: University of Florida, 2000. 39 p. 
JENKINS, T. C.; McGUIRE, M. A. Major advances in nutrition: impact on milk composition. Journal of Dairy Science, Illinois, v. 89, n. 4, p. 1302-1310, 2006.

JOHNSON, A. D. Sample preparation and chemical analisys of vegetation. In: MANEJTE, L.T. (Ed.). Measurement of grassland vegetation and animal production. Aberustwysth: Commonweath Agricultural Bureax, 1978. p. 96-102.

JORDAN, E.; KENNY, D.; HAWKINS, M.; MALONE, R.; LOVETT, D. R.; O'MARA, F. P. Effect of refi ned soy oil or whole soybeans on intake, methane output, and performance of young bulls. Journal of Animal Science, Illinois, v. 84, n. 9, p. 2418-2425, 2006.

MERTENS, D. R. Creating a system for meeting the fiber requirements of dairy cows. Journal of Dairy Science, Illinois, v. 80, n. 7, p. 1463-1481, 1997.

MIR, P. S.; MEARS, G. L; MIR, Z. Vegetable oil in beef cattle diets. In: BEAUCHEMIN, K. A.; CREWS, D. H. (Ed.). Advances in beef cattle science. Lethbridge: Lethbridge Research Centre, 2001. p. 88-104. v. 1.

NATIONAL RESEARCH COUNCIL - NRC. Nutrient requeriments of dairy cattle. 7. ed. Washinton, D.C.: $2001.381 \mathrm{p}$.

OLIVEIRA, A. S. Co-produto da extração de óleo de sementes de mamona e de girassol na alimentação de ruminantes. 2008. Tese (Doutorado em Zootecnia) Universidade Federal de Viçosa, Viçosa.

OLIVEIRA, M. D. S.; RÊGO, A. C.; SFORCINI, M. P. R.; FREITAS JÚNIOR, J. E.; SANTOS, J.; CARVALHO, M. V. Bromatological characteristics and in vitro digestibility of four sugarcane varieties subjected or not to the application of quicklime. Acta Scientiarum Animal Sciences, Maringá, v. 34, n. 4, p. 355-361, 2012.

PIMENTEL, J. J. O.; LANA, R. P.; GRAÇA, D. S.; MATOS, L. L.; TEIXEIRA, R. F. A. Teores de proteína bruta no concentrado e níveis de suplementação para vacas leiteiras em pastagens de capim-braquiária cv. Marandu no período da seca. Revista Brasileira de Zootecnia, Viçosa, v. 40, n. 2, p. 418-425, 2011.

PINA, D. S.; VALADARES FILHO, S.C.; VALADARES, R. F. D.; DETMANN, E.; CAMPOS, J.M. S.; FONSECA, M. A.; TEIXEIRA, R. M. A.; OLIVEIRA, A. S. Síntese de proteína microbiana concentrações de ureia em vacas alimentadas com diferentes fontes de proteína. Revista Brasileira de Zootecnia, Viçosa, v. 35, n. 4, p. 15511559, 2006.
RIBEIRO, S.; CHAVES, L. H. G.; GUERRA, O. C.; GHEYIS, H. R.; LACERDA, R. D. Resposta da mamoneira cultivar BRS-188 Paraguaçu à aplicação de nitrogênio, fósforo e potássio. Revista Ciência Agronômica, Fortaleza, v. 40, n. 4, p. 465-473, 2009.

SCHIO, A. R.; VELOSO, C. M.; SILVA, F. F.; ÍTAVO, L. C. V.; MATEUS, R. G.; SILVA, R. R. Ofertas de forragem para novilhas Nelore suplementadas no período de seca e transição seca/águas. Acta Scientiarum Animal Sciences, Maringá, v. 33, n. 1, p. 9-17, 2011.

SILVA, C. V.; LANA, R. P.; CAMPOS, J. M. S. Consumo, digestibilidade aparente dos nutrientes e desempenho de vacas leiteiras sob pastejo em função de níveis de concentrado e proteína bruta na dieta. Revista Brasileira de Zootecnia, Viçosa, v. 38, n. 7, p. 1372-1380, 2009.

SKLAN, D.; ASHKENAZI, R.; BRAUN, A. Fatty acids, calcium soaps of fatty acids and cottonseeds fed to high yielding cows. Journal of Dairy Science, Illinois, v. 75, n. 9, p. 2463 2472, 1992.

SOUSA, D. P.; CAMPOS, J. M. S.; VALADARES FILHO, S. C.; VALADARES, R. F. D.; SEDIYAMA, C. A. Z.; CRUZ, J. C. C. Parâmetros fermentativos, produção de proteína microbiana, concentrações de ureia no leite e no plasma e balanço de nitrogênio de vacas alimentadas com silagem de milho ou cana-de-açúcar com caroço de algodão. Revista Brasileira de Zootecnia, Viçosa, v. 38, n. 10, p. 2063-2071, 2009.

TEIXEIRA, R. M. A.; LANA, R. P.; FERNANDES, L. O. Efeito da adição de concentrado em dietas de vacas gir leiteiro confinadas sob a produção de leite. In: REUNIÃO ANUAL DA SOCIEDADE BRASILEIRA DE ZOOTECNIA, 43., 2006, João Pessoa. Anais... João Pessoa: Sociedade Brasileira de Zootecnia, 2006. CDROM.

VALADARES, R. F. D.; BRODERICK, G. A.; VALADARES FILHO, S. C.; CLAYTON, M. K. Effect of replacing alfafa with high moisture corn on ruminal protein synthesis estimated from excretion of total purine derivatives. Journal Dairy Science, Illinois, v. 82, n. 12, p. 2686-2696. 1999.

VASCONCELOS, A. M.; LEÃO, M. I.; VALADARES FILHO, S. C.; VALADARES, R. F. D.; DIAS, M.; MORAIS, D. A. E. F. Parâmetros ruminais, balanço de compostos nitrogenados e produção microbiana de vacas leiteiras alimentadas com soja cru e seus subprodutos. Revista Brasileira de Zootecnia, Viçosa, v. 39, n. 2, p. 425-433, 2010. 
